\title{
Poverty Situation of Cocoa Smallholders and Its Determinant in West Sulawesi, Indonesia
}

\author{
Nurlaela \\ Department of Agribusiness, Faculty of Agriculture and Forestry, \\ West Sulawesi University, Jln Prof. Dr. Baharuddin Lopa, West Sulawesi 91412 Indonesia \\ Tel./Fax.+62-422-22559 Email: nurlaelaunsulbar@gmail.com \\ Muhammad Arafat Abdullah \\ Department of Agribusiness, Faculty of Agriculture and Forestry, \\ West Sulawesi University, Jln Prof. Dr. Baharuddin Lopa, West Sulawesi 91412 Indonesia \\ Tel./Fax.+62-422-22559 Email: arafatmandar@gmail.com
}

(Received: Oct 25, 2016; Reviewed: Nov 15, 2016; Accepted: May 10, 2017)

\section{DOI: http://dx.doi.org/10.20956/ijas.v5i1.1174}

\begin{abstract}
Poverty of cocoa smallhoders is still identifed as a serious issue in Indonesia. The general specific objectives of the research is to calculate the percentage of cocoa smallholders are living below the Provincial Poverty Line and identifying determinant affects poverty of smallholders. The research employed Head Count Index and Path Analysis. Results show that the percentage of cocoa farmers living below Poverty Line reached $65 \%$ in the province. Determinant factors affects poverty situation is education attainment of family member, access to price information, cocoa estate area, distance to school. It suggests that in order to reduce poverty of cocoa farmers need to improve children and education attainment, making school is more closer to the farmers community and develop cocoa estate area and connecting price information to the farmers.
\end{abstract}

Keywords: Cocoa smallholders; Poverty Index

\section{Introduction}

Poverty is a worldwide problem hit developing countries seriously. Cocoa smallholders are a part of the problem to solve, indicating that it have been facing rural coastal and agricultural poverty as long term issues. Needless to say, the issue was (and still is) stretched out from rural agriculture to rural coastal area and this is a reason why rural poverty cannot be neglected in these countries, needs to pay strong attention on it, in other words. It was already pointed out in elsewhere that, poverty needs specific commitment and political will to attack (Arsyad et al., 2014). Cocoa consistently as a source of foreign exchange in 2006 reached US \$ 855 million, a very important contribution in the structure of the Indonesian economy. Moreover, as the cocoa plantation sub-sector is the leading sector in the national employment reached about 400 thousand farm households. On the side of trade between countries, almost all cocoa products Indonesia used to meet export market (up 80.64\%) and continues to experience growth of around $15 \%$ over the last twenty years to the countries major importers such as the United States and the Netherlands (Arsyad et al., 
2011). Likewise, domestic consumption as a raw material in the domestic industry (grindings) continues to increase every year. Indonesia is the third-world cocoa producer after Cote d'Ivoire and Ghana. Sulawesi accounts for $72 \%$ of national production. In 2013, West Sulawesi cocoa production reached 149458 tonnes spread across all districts in West Sulawesi. West Sulawesi accounts for $24 \%$ of national production. This proves that the West Sulawesi important role in national cocoa trade.

Referring to the results SUSENAS 2003 , approximately $70 \%$ of the poor work in agriculture, including cocoa plantations in West Sulawesi (Arsyad \& Ali, 2009). The phenomenon lately shows the number of farmers in the South West to replace cocoa plants with other crops (short term), because of insufficient income from cocoa as annual crops for subsistence. This indicates that the insufficiency or poverty can have an impact on the structure of production. If this happens, then it is very difficult to expect to exceed the position of cocoa production Ivory Coast and Ghana. With this situation, the government of West Sulawesi cocoa production as the main base, also in desperate need of synergy between policy and production (cocoa) at the farm level, which is still poor. Indonesia is the third-world cocoa producer after Ivory Coast and Ghana with the total national production of 536804 tonnes in 2001 to 748828 tonnes in 2005. The production growth during this period reached $10.49 \%$ per year, a very substantial growth with the highest growth of $21.55 \%$ in 2001 . the escaped the attention of the total production is achieved, approximately $90.83 \%$ over the period 2001 to 2005 is produced by growers who do subsistence folk (traditional) by smallholders who are poor. Then the remaining $3.41 \%$ of the plantations government (PTPN) and 3.95\% private estates (see also Arsyad et al., 2011). It is clearly that the contribution of the smallholders to the Indonesian cocoa estate is dominantly.

This fact shows that the importance of the contribution of Senior High School cocoa farmers in increasing production (with growth of $11.69 \%$ per year higher than the national average growth of $10.49 \%$ per year). The situation above carries an important message that cocoa production of Indonesia where West Sulawesi province as one of the main contributors can not be separated from cocoa smallholders itself, which is still very poor. Then, although there is no separate data between the export volume of cocoa produced by Senior High Schoolllholder, government and private, but if seen the value of cocoa exports in 2005 (approximately US \$ 668 million), and the calculated percentage of production $(90 \%)$, then the actual contribution of Senior High School farmers impoverished cocoa export earnings reached US \$ 606 million, an extraordinary contribution in the economy. This indicates that if Indonesia does not have a smallholders who continuously produce, then Indonesia will not be able to avoid a decline in cocoa production growth, which will result in reduced volume and value of exports, however, would further send the negative impact on foreign exchange. So the next urgent problem was soon overcome poverty cocoa farmers in West Sulawesi as one of the spearheads of the national cocoa production 
and exports. The general specific objectives of the research is to calculate the percentage of cocoa smallholders are living below the Provincial Poverty Line and identifying determinant affects poverty of smallholders

\section{Method}

\subsection{Data and Research Site}

The main data was collected by surveying at the farm level with the instrument questionnaires. for calculating the percentage of farners who are living below poverty line and its determinant. Data was processed by SPSS 8.50. The research site was selected by XY Scatter Plot Method with two locations: the main characteristics; (1) The location has a high rate of poverty and the number of smallholders is also high; (2) The location has a number of cocoa farmers is relatively the same, but the severity of poverty is different (Arsyad, et al., 2010). The number of samples of farmers (random) planned proportional to each study site to be interviewed using a questionnaire.

\subsection{Head Count Index}

To calculate the percentage of percentage of cocoa farmers who are living below the provincial poverty line, the analysis used the Foster-Greer-Torbecke poverty indices (Arsyad et al., 2014) by following formula: $\mathrm{HCI}=\mathrm{q} / \mathrm{n}$; where $\mathrm{q}$ is the number of poor and $\mathrm{n}$ is the total sample.

\subsection{Path Analysis}

The research used Path Analysis to identify direct effect of independent variable on dependent (however, indirect effect will not explain in this paper). In this study, the regression method (as Path Analysis) used was Backward by entering the independent variables associated with poverty, so that they can be identified through Path Analysis. Path Analysis equation used to analyze poverty as follows:

$\begin{aligned} \mathrm{Y} & =\mathrm{b}_{0}+\mathrm{b}_{1} \mathrm{X}_{1}+\mathrm{b}_{2} \mathrm{X}_{2}+\ldots+\mathrm{b}_{\mathrm{k}} \mathrm{X}_{\mathrm{k}}+\mathrm{E}_{\mathrm{t}} \\ \text { Where: } & =\text { variabel dependen } \\ \mathrm{Y} & =\text { intercept of the equation } \\ \mathrm{b}_{0} & =\text { regression coefficients } \\ \mathrm{b}_{1, \ldots \mathrm{k}} & =\text { independent } \\ \mathrm{X}_{1, \ldots \mathrm{k}} & =\text { error term } \\ \mathrm{E}_{\mathrm{t}} & =\end{aligned}$

\section{Results and Discussion}

\subsection{Head Count Index}

The calculation reveals that Head Count Index (HCI) of Poverty in Cocoa Smallholders is .650. It means that around $65.00 \%$ of the farmer households have an income/ capita/month below the Poverty Line (PL). This shows that the majority of cocoa farmers in West Sulawesi province live in poor conditions so that the necessary efforts for the government to be able to improve their welfare.

\subsection{Path Analysis}

The overall test persuasively resulted in the rejection of Null Hypothesis that "there is no significant impact of independent variables on dependent". This could be proved that all regression coefficients in the equation are zero. The regression results show $\mathrm{R}^{2}$ of equation reached 0.712 . It means that, $71.20 \%$ of the total variance of "Household Income" in general, can be explained so fairly robust by all explanatory variables. Thereby, we may say that the model constructed through the dimensions 
in the research is adequate in explaining the poverty situation of cocoa smallholders. Path analysis model is shown below:

$\mathrm{Y}=2475041.681+0.926 \mathrm{X}_{1}+847839.936 \mathrm{X}_{2}$ $+256754.425 \mathrm{X}_{3}+260776.403 \mathrm{X}_{4}-1162.121 \mathrm{X}_{5}-$ $829.098 \mathrm{X}_{6}$

Where:

$\mathrm{Y}=$ Income Cocoa Farmers

$\mathrm{X} 1=$ Price Information Into Farmers

$\mathrm{X} 2=$ Children's Education

$\mathrm{X} 3=$ Total Area Gardens Cocoa

$\mathrm{X} 4=$ Education Wife

$\mathrm{X} 5=$ Distance to senior high school

X6 = Distance to junior high school

It is clearly understand that the model shows a number of variables significantly affect the income of cocoa farmers (0.05). They are Education, Price Information, Cocoa Area, Distance to Junior and Senior High Schools. Some important findings can be explained:

\subsubsection{Education attainment}

Analysis shows that the variable "Education attainment" will affect poverty situation. It can be interpretated that the higher level of education attainment in the family, the higher cocoa smallholders income will be. This indicates that the education level of family farmers need to be improved in order to increase family income, reducing poverty of smallholders in other words.

\subsubsection{Price information}

Another important finding in the analysis is the variable "Price Information". The regression results indicate that the higher the frequency of information Prices to the farmers will Increase their income. Another words, price information of agricultural products will affect directly on the increase in agricultural revenue that would reduce the level of cocoa smallholders poverty. This also happen in Cocoa Markets (2014) that World prices, and the proportion of export price captured by smallholders, and the wages paid to labourers on cocoa farms, have a critical bearing on poverty and vulnerability, including the ability of rural households to meet health and education costs. As Kuapa Kokoo Ghana (2006) suggested to provide access to market information in order to ensure local development and a long-term source of supply of cocoa for their production. This is also in line with EASRD (2005) findings that access to capital and fertilizer, onset of various diseases in cash crops (particularly Cocoa Pod Borer), poor linkages to markets and poor perception of price signals from markets.

\subsubsection{Cocoa area}

The next crucial findings in the analysisi is the variable "Cocoa Harvested Area". Regression results showed that the more the Cocoa Area will Increase cocoa farmer production, then in turn will increase their income. This situation will affect directly the total number of income and naturally will reduce poverty situation of the farmers.

\subsubsection{Distance to senior high school}

Another interesting variable affect the poverty situtaion of cocoa smallholders is "Distance to Junior High School". Regression results indicate that the farther the distance to juniror high school from farmers community, the lowers the income will be. This is reasonable finding. If the school is 
too far from the community, then farmers need to pay (as a cost) motorcycle taxi operators in order to let their kids get in school. This will affect income farmers (reduce purchasing input for agricultural input), then in turn will decrease production. This gives important message that if the school is too far away from the community will exacerbate poverty situation.

\subsubsection{Distance to junior high school}

The last independent variable is also affect the poverty situtaion of cocoa smallholders is "Distance to Junior High School". Samething happen in variable "Distance to Junior High School" (eventhough the size is different). Regression results indicate that the farther the distance to juniror high school from farmers community, the lowers the income will be. This is reasonable finding. If the school is too far from the community, then farmers need to pay (as a cost) motorcycle taxi operators in order to let their kids get in school (once again). This will affect income farmers (reduce purchasing input for agricultural input), then in turn will decrease production. This gives important message that if the school is too far away from the community will exacerbate poverty situation. The last two findings make s clear that the closer the school to the cocoa smallholders will help poverty reduction.

\section{Conclusion}

It can be concluded that the percentage of cocoa farmers living below Poverty Line reached $65.00 \%$ in the province. Determinant factors affects poverty situation is education attainment, access to price information, cocoa estate area development, and distance to school (especially senior and junior High Schools). It suggests that in order to reduce poverty of cocoa farmers need to improve family education attainment, making school is more closer to the farmers community, develop cocoa estate area and connecting price information to the farmers.

\section{Acknowledgement}

Authors would like to extend sincere thanks to Muhammad Arsyad, Ph.D. (Hasanuddin University) for his valuable discussion during the research construction and providing some references in writing this paper. No one read early drafts as intensively as Dr Arsyad does. Special thanks is also going to $\mathrm{Dr}$ Akhsan (President, West Sulawesi University, WSU), Mr Anwar Sulili (Vice president for financial affairs, WSU) and Dr A Kadir Paloloang (Director, Research Center and Community Services, WSU) for their attention and technical support to this research. Thanks to Directorate General of Higher Education, Ministry of Research, Technology and Higher Education, Indonesia for 2 years financial support (Research Collaboration Grant, HIBAH PEKERTI/PKPT) enable us finished the research.

\section{References}

Arsyad, M., A. Nuddin, M.Y. Zamhuri, S. Yusuf, (2014). The Poverty Reality of Coastal and Agriculture: How Severe the Seaweed Farmers and Cocoa Smallholders Are? . International Journal of Agriculture System, 2(2):119131. 
Arsyad, M., B.M. Sinaga, S. Yusuf, (2011). Analysis of Impact of Tax Policy of exports on Indonesian Cocoa Export Production Post-Uruguay Round. Journal Sosial Ekonomi Pertanian. 8 (1): $63-$ 71.

Arsyad, M., S. Yusuf, (2010). Causes-Senior High Schoolllholders Poverty Linkages: A Comparison of Two Villages in Indonesia, Ryukoku Journal of Economic Studies, 49 (4): 55-74.

Arsyad, M., B. Sanim and B.M. Sinaga, (2004). Impact of Devaluation Policy on Cocoa Production and Export of South Sulawesi. Journal Forum Pascasarjana. Graduate School, Institut Pertanian Bogor. 27 (3): 255-269.

Arsyad, M., D. Ali, (2009). Does Agriculture Really Alleviate Poverty? Lesson from Indonesian Economic Evidence. Ryukoku Journal of Economic Studies, 48 (3).

Center for Estate Crops Research Institute (CRIEC) - World Bank, (2002). The Performance Analysis of Cocoa (Report Studies on Senior High Schoolllholder Tree Crops Production and Poverty Alleviation). CRIEC-World Bank, Bogor.

Cocoa Market, (2014). Background of the Study. (unpublished).

Dradjat, B., R. and T. Suprihatini Wahyudi, (2001). Prospects and Development Strategy Analysis of Downstream In- dustrial Plantation: Cocoa Case. Final report. Research and Development Project section, Plantation Plantation Research Association, Agency for Agricultural Research and Development, Bogor.

EASRD, (2005). Public Private Partnerships for Agriculture in Eastern Indonesia: A Comparative Study of the Beef Cattle and Cocoa Industries. Technical Note was prepared for the World Bank. Technical notes are prepared as part of the World Bank work. The contents do not necessarily represent the official Bank view, nor have been formally reviewed with Government.

Hutabarat, B., Palm, M.H., Saktyanu, K.D., Purba, H.J., Wahida and Nuryanti, S., (2007). Analysis of Free Trade Agreement between Indonesia and China and AFTA Cooperation and Its Impact on Agricultural Commodity Trading Indonesia. Research Final Report. Economic and Social Research Center for Agricultural Policy, Agency for Agricultural Research and Development, Bogor.

Kuapa Kokoo Ghana (2006). Case Study on Cocoa in Ghana. Prepared for the meeting on Aid for Trade co-organized by Realizing Rights: The Ethical Globalization Initiative and The Mission of Ireland to the United Nations, Geneva. 